\title{
Constructing a 'Great' Role for Britain in an Age of Austerity: Interpreting Coalition Foreign Policy, 2010-2015
}

\author{
Oliver Daddow
}

\begin{abstract}
This article interprets the ideational underpinnings of the British Conservative-Liberal coalition government's foreign policy from 2010 to 2015. It uses qualitative discourse analysis of speeches, statements and policy documents to unpack the traditions of foreign policy thought which informed some of the key foreign policy practices of the coalition government. The analysis centres on the British identity constructed by liberal Conservatives, and the values and interests flowing from this baseline identity that the government's foreign policy sought to express through its foreign policy. Liberal Conservative foreign policy is argued to have been an attempt to come to terms with the limits on Britain's international agency in the face of three major foreign policy dilemmas: the legacy of the New Labour years; dramatically reduced economic resources in the 'age of austerity'; and an increasingly restricted capacity for Britain to exercise ideational entrepreneurship in the international community. The article substantiates the claim in the extant literature, that liberal Conservatism significantly adapted but did not restructure an established British foreign policy tradition of merging values and interests in complex ways.
\end{abstract}

Keywords: Britain; foreign policy; interpretivism; liberal Conservatism; David Cameron; William Hague 
Interpretivist research into foreign policy (see the introduction to this Special Issue) has usefully highlighted the dynamic interplay between beliefs about national identity, ${ }^{2}$ national role conceptions, ${ }^{3}$ and how these constructions are negotiated domestically and expressed internationally through foreign policy practices. The objective of this article is to build on this emerging research programme through a discourse account of the foreign policy practices of the Conservative-Liberal coalition that governed Britain for five years between May 2010 and May 2015. This is an emerging strand within a wider field, where considerable work remains to be done. ${ }^{4}$

Under David Cameron's leadership from December 2005 the Conservative Party unveiled a foreign policy agenda it dubbed the 'liberal Conservative' approach to foreign affairs: 'Liberal - because I support the aim of spreading freedom and democracy, and support humanitarian intervention. Conservative - because I recognize the complexities of human nature, and am sceptical of grand schemes to remake the world' ${ }^{5}$ The liberal Conservative approach was rolled out in the 2010 Conservative Party election manifesto, ${ }^{6}$ where it was used to stake out clear water between it and its principal electoral rival, the Labour Party. Cameron and his foreign policy team wanted a return to traditional Conservative pragmatism in the conduct of external relations: "more measured and modest ambition and closer attention paid to the national interest', while retaining Labour's ethical commitments to non-citizens overseas. ${ }^{7}$ The era of military overstretch caused by Tony Blair's adventurism in Iraq and Afghanistan, however, was over.

As Matt Beech has pointed out, on foreign policy Cameron drew upon Liberal and Conservative traditions for inspiration, ${ }^{8}$ meaning that his outlook closely resembled that set out in the Liberal Democrat 2010 election manifesto, which privileged multilateralism, aid, human rights and commitment to a rules-based international order. ${ }^{9}$ The Conservatives were strongly in favour of reinvigorating ties with the Commonwealth and the wider 'Anglosphere' was predominant in its foreign policy section, ${ }^{10}$ yet this was strongly implied in the Liberal 
Democrat manifesto too. ${ }^{11}$ As a result, foreign policy was not a big source of disagreement during the negotiations that led to the agreement to form the coalition government on 20 May 2010. ${ }^{12}$ Where there was discord, such as over Britain's future role in the European Union (EU) policy or the renewal of the nuclear missiles, 'they were postponed by simply making firm commitments - but not yet; and cast forward into a future parliament' ${ }^{13}$ Cameron in fact had more to worry about from his own Eurosceptic backbenchers than the Liberal Democrats, ${ }^{14}$ although it was evidently a testing part of the coalition negotiations in $2010 .{ }^{15}$ Cameron and Liberal Democrat Deputy Prime Minister Nick Clegg did not want to sacrifice coalition cohesion at the altar of partisan spats in foreign affairs.

To investigate the foreign policy practices undertaken on the back of the liberal Conservative reading of international relations, the article begins by explaining the discourse approach taken to the data. The second part analyses how the coalition government thought about Britain's identity and its accompanying role in a globalized world. The third part outlines how liberal Conservatism construed the interplay between values and interests in British foreign policy to inform a series of foreign policy practices that drew strong conceptual connections between aid, development and security. The key claim made below agrees with Rhiannon Vickers's view that 'it is possible to discern an overall foreign policy approach of liberal Conservatism that was liberal enough to satisfy the Conservatives' Coalition partners, while rejecting the more idealistic tenets of new Labour's foreign policy. ${ }^{16}$ The distinctive threads of this approach were, firstly, its concentration on the economics of foreign policy; second, its use of all the tools of 'soft power' at Britain's disposal to attain a 'great' power role; and, finally, its recognition of the stricter limits on Britain's capacity to exert ideational entrepreneurship in an era of declining resources, rising powers, new security challenges and the decline of American hegemony.

\section{Interpreting liberal Conservatism}


This article explores liberal Conservatism using qualitative discourse analysis of primary sources, to demonstrate how the resulting foreign policy practices gave meaning to those beliefs. The central aim of a discourse approach is 'to understand how specific human beings in particular times and locales make sense of their worlds' ${ }^{17}$ Discourse analysis identifies the textual markers and conceptual hooks on which discourse producers hang their webs of belief about the nature of 'reality', ${ }^{18}$ treating, in this case, foreign policy decision-makers as situated agents (see the introduction to this Special Issue) operating in embedded institutional and social contexts. Three preparatory remarks are in order to scope the analysis that follows.

The first is that secrecy and access issues seriously affect the study of foreign policy, especially in relatively 'closed' foreign policy-making environs such as in Britain. Semistructured elite interviews were conducted with individuals very close to the events in question. However, the interviewees, many of them still active in public life, did not give permission to be cited in this article. The use of public pronouncements and official documents is a pragmatic riposte to the practical limitations on researching the dynamics of foreign policy activity. Second, the discourse data was drawn from speeches by the key architects of liberal Conservatism: David Cameron (Prime Minister from May 2010 to the present); William Hague (Foreign Secretary May 2010 to July 2014); and Philip Hammond (Secretary of State for Defence from October 2011 and Hague's replacement in July 2014). This is not to deny that the Liberal Democrats left many significant imprints on the governance of Britain, for example, by helping safeguard civil liberties in the enactment of anti-terror legislation, ${ }^{19}$ and by keeping up pressure on the government to commit future governments to spending $0.7 \%$ of national income on aid, ${ }^{20}$ which bore fruit in the International Development Act of March 2015. ${ }^{21}$ However, the Liberal Democrats possessed 'junior status in the coalition', ${ }^{22}$ and it is noteworthy that in terms of individuals involved in the foreign policy decision-making process there was clear Conservative domination at departmental level, notably the Foreign and Commonwealth Office (FCO), the Department 
for International Development (DfID), and the newly created body for coordinating national security, the National Security Council (NSC). ${ }^{23}$ Third, the discourse method is informed by work on the constructed nature of Britain's world role,${ }^{24}$ and the part played by the study of discourse in understanding the dynamics behind identity creation, role promotion and external action on the part of states. ${ }^{25}$ Crucially, this body of work points to a direct connection between national identity and foreign policy practices. ${ }^{26}$ As Jamie Gaskarth has written: 'Having a strong self-identity and sense of Britishness is seen as important to British foreign policymakers, both in mobilizing support for governmental actions abroad, and to give those actions meaning' ${ }^{27}$

The discourse analysis below is themed around two sets of questions. The first unpicks the coalition's beliefs about identity and Britain's global agency in an age of austerity and post-New Labour adventurism: 1a, How did liberal Conservatism construct British identity and $1 \mathrm{~b}$, What kind of world did liberal Conservatives see Britain exerting agency in? Research question 2 developed Jonathan Gilmore's useful emphasis on the uneasy balance of interests and values in liberal Conservative foreign policy: 2a, How did liberal Conservatism define the British national interest? 2b, What values did liberal Conservatism seek to promote or protect? 2c, How did liberal Conservatism express British interests and values on the world stage through its foreign policy practices?

\section{Britain's identity and role in the world}

The evidence in this part of the article corroborates a major finding in the flourishing work on liberal Conservatism, that coalition foreign policy-makers devised policy in the belief that they were acting on behalf of a British national community possessing values and an identity which lies 'deep in our DNA as a nation'. ${ }^{28}$ Understanding liberal Conservative beliefs about identity and the role conception it gave rise to are key to understanding the ways in which Britain could exert agency internationally through its foreign policy practices, even in an era 
of 'rising states' and now polarities in international affairs. It is important to note that this analysis does not attempt a thoroughgoing critique of the various beliefs about coalition foreign policy recorded below, although clearly the data presented could be used to inform such an enterprise, particularly around the issues of the restrictive role conception on offer, ${ }^{29}$ the definition of the 'national interest', ${ }^{30}$ and the manifest gaps between rhetoric and practice in the realm of Britain's commitment to an 'ethics' in its foreign policy activity. ${ }^{31}$

To answer the first research question (1a, How did liberal Conservatism construct British identity?) liberal Conservatism accented innate British 'assets and advantages' as the baseline for thinking about how the national community could express itself internationally. This was very much a New Labour foreign policy tradition too, ${ }^{32}$ Cameron and Hague both subscribed to the list, ${ }^{33}$ as later did Philip Hammond. ${ }^{34}$ This list of British qualities was also deployed to explain the thinking behind policies contained in key policy documents such as the 2010 National Security Strategy (NSS). ${ }^{35}$ What were these British qualities and resources? First of all, liberal Conservatism flagged up a series of material coercive capabilities, with special reverence for 'the hard power of our military' and the nation's 'brilliant armed forces' ${ }^{36}$ Second, Britain could call on an impressive roll call of diplomatic ties, partly but not exclusively a legacy of its imperial past: 'We sit at the heart of the world's most powerful institutions, from the G8 and the G20, to NATO [North Atlantic Treaty Organization], the Commonwealth, and the UN Security Council'. ${ }^{37}$ Hammond certainly felt that Britain's embeddedness in all the relevant regional and international orgnisations ties meant 'Britain remains one of the few countries in the world that can set the global foreign policy agenda', its multilateral ties helping it deal with thorny dilemmas such as Russian revanchism in the Ukraine. ${ }^{38}$ Third, Britain was also said to be 'a great economic power' and a 'great trading force in the world'. ${ }^{39}$ It was home to 'one of the most open economies on earth' centring on the City of London which helped 'power the world economy'. ${ }^{40}$ The launch of the 'Britain is GREAT' global promotional campaign, launched in 2012 to coincide with the Queen's 
Diamond Jubilee and the London Olympic Games, ${ }^{41}$ shows how strongly the Prime Minister and both his Foreign Secretaries believed that external relations and economic policy were mutually constitutive: 'our foreign policy must also support our long-term economic plan'. ${ }^{42}$ Here, the Conservative Party's neoliberal economic thought helped inform liberal Conservative practices, with neither Cameron, Hague nor Hammond recoiling from mixing 'money and diplomacy'43 and rejecting criticisms from the Labour Party that this was 'low grade mercantilism'. ${ }^{44}$ In fact, they contended, 'in the [Labour] past' this was what went wrong with British foreign policy: 'We forgot old friends, missed new opportunities and damaged Britain's interests as a result' ${ }^{45}$

On a day to day basis this agenda was enacted through the Diplomatic Excellence Initiative for the FCO. Launched in December $2010,{ }^{46}$ and publicized by Hague in a September 2011 speech, the objectives were: to expand Britain's diplomatic network; to improve the institution's skills and organisational memory; and to put its budget on a surer footing by decoupling it from the fluctuating value of sterling in the global currency markets. ${ }^{47}$ FCO diplomats were encouraged to be more than 'political ambassadors' - why not be 'economic ambassadors too'? Because in a 'global race for jobs' every new market needed exploiting, feeding what Cameron called a 'modern industrial strategy'. ${ }^{48}$ Being 'smarter' about making and executing foreign policy overlapped with being 'smarter' about national security: 'we also have to be more strategic and hard headed about how we go about advancing our national interests', particularly in terms of matching commitments to resources in defence terms. ${ }^{49}$ The creation of the NSC, the contents of the NSS and the accompanying Strategic Defence and Security Review were all driven by the need to 'ensure that ministers consider national security in the round and in a strategic way' ${ }^{50}$

These beliefs about Britain's material assets and advantages were used to support the characteristically Conservative emphasis on nationhood, embodied in the opinion that, despite confronting a series of interlocking domestic and international crises, Britain could still be 
seen to be 'walking tall abroad' 51 by allying its material capabilities to 'soft power' capabilities. ${ }^{52}$ As Philip Hammond recalled of the thought processes in 2010, 'we understood from the outset that the world would not stand still while we picked ourselves up and addressed our weaknesses' on the resource side. ${ }^{53}$ Not for liberal Conservatives pulling up 'the drawbridge' to the outside world, ${ }^{54}$ being 'on the defensive', ${ }^{55}$ succumbing to 'strategic shrinkage' (a key liberal Conservative headline) ${ }^{56}$ or accepting a strategy 'set to decline'.${ }^{57}$ The NSS affirmed the collective view: 'We are a country whose political, economic and cultural authority far exceeds its size' ${ }^{58}$ Britain's 'soft power' capabilities were said to span a number of cultural dimensions, ${ }^{59}$ which, as recognised by commentators such as Christopher Hill and Sarah Beadle, could be mobilized 'to influence the behaviour of others and obtain desired outcomes through attraction and co-option' ${ }^{60}$ To begin, the English language 'one of the great languages of humanity', ${ }^{61}$ and 'the global language of business', ${ }^{62}$ which gained added influence through institutions such as the BBC. ${ }^{63} \mathrm{Next}$, the 'intercontinental reach of our time zone', ${ }^{64}$ whereby 'you can trade with Asia in the morning and America in the afternoon'. ${ }^{65}$ Britain further benefitted from its 'world-class universities', ${ }^{66}$ and a 'pioneering, buccaneering spirit', ${ }^{67}$ that introduced to the world 'the modern computer and the World Wide Web'. ${ }^{68}$ Then there were the wider benefits from the 'cultural impact' of such institutions as the British Council and the heritage industry around 'our great museums' ${ }^{69}$ Finally, there was the 'unrivalled history of democratic, legal and political development' inculcated in the British system of government, ${ }^{70}$ much exported, and incorporating 'a civil service and a diplomatic service which are admired over the world for their professionalism and their impartiality'. ${ }^{71}$ Conservative eulogies to the qualities of the British nation were prominent in informing coalition foreign policy practices, and having reviewed these we now consider the kind of world in which liberal Conservatives saw Britain expressing its agency.

Liberal Conservatives answered the second question $1 \mathrm{~b}$, What kind of world does Britain exert agency in? by interweaving two mutually reinforcing sets of beliefs about how 
national security was to be safeguarded in an age of uncertainty. In the first place, liberal Conservatives assumed that the defining feature of this 'new' world was that it was 'networked' (here, Hammond name-checked Hague, showing the consistency across the change of FCO leadership), ${ }^{72}$ 'interconnected', interdependent (a Blair favourite) ${ }^{73}$ and home to a 'world of restless markets'. ${ }^{74}$ However, Liberal Conservatives went further than New Labour did in accenting the downsides as well as the upsides of globalization in the realms of security and the global distribution of economic gains, ${ }^{75}$ illustrating how traditions adapt as they confront new policy challenges and new knowledge about the international arena - in this case loss of faith in progress towards the building of a liberal post-Cold War world order. Hammond, for instance, spoke of 'a world laden with risk, yet rich in opportunity'. ${ }^{76}$ Hard and soft security vulnerabilities both featured prominently in liberal Conservative discourse. Soft threats included threats to the economy, for example to the City from cyber attacks, ${ }^{77}$ from climate change, or from instability in the Middle East and Eastern Europe affecting Britain's access to global energy supplies. ${ }^{78}$ Soft threats in this depiction clearly had the potential to augment hard threats such as violent extremist terrorism and Russian aggression in Ukraine. Liberal Conservatism also posited that 'failed states' were not containable within sovereign borders but their problems would leak out to affect the international community as a whole. Cameron used the example of Somalia in 2011: 'a failed state that directly threatens British interests' defined in terms of: civilians (kidnappings of tourists and aid workers), trade (routes being disrupted by piracy), migration, and ideology ('minds poisoned by radicalism'). ${ }^{79}$ Meanwhile, instability in countries such as Libya 'underlined the need for us to reshape our armed forces as rapidly as possible' because it flagged the need for 'a different kind of military to meet different kinds of threat' ${ }^{80}$

Drawing this section to a close, it can be seen that liberal Conservatives saw the goal of national foreign policy practices as being to enhance both the prosperity and the security of a community of people possessing a relatively cohesive set of 'cultural' properties 'deep in 
their DNA' This gave rise to a series of reflections on both the upsides and downsides of being a formerly major power operating in an interdependent global arena. Accepting Britain's reduced place in the 'hierarchy of nations', ${ }^{81}$ liberal Conservatism nonetheless suggested that Britain need not settle for second class status, even in an age of domestic austerity. The role liberal Conservatism identified for Britain was thus of a 'great' power of a different kind, using all the skills and qualities provided by its soft power assets. How this identity and role construction fed particular liberal Conservative foreign practices will be amplified in the next section through a discussion of liberal Conservative discourse on promoting British values and interests through its foreign policy.

\section{British interests and values}

The previous section illustrated the key ways in which liberal Conservativism focussed on the economics of foreign policy and the plethora of 'soft power' capabilities that could help Britain achieve its external goals by persuasion and ideational attraction rather than via the blunt exercise of coercive power. This section will suggest that this exercise in rebranding British identity was accompanied by an acceptance that British values and interests could no longer be universalized or imposed globally, as arguably New Labour had attempted to do by following in the slipstream of US neo-conservatism. There was a strongly Conservative accent on the pragmatic pursuit of interests allied, not always comfortably, to a continuing expression of ethical commitments to non-citizens.

The Conservative focus on interests was manifest in the way the speeches dealt with the baseline target for foreign policy. For example, in 2009 Hague defined foreign policy as 'the protection and promotion of our national interest' ${ }^{82}$ In his 2010 Lord Mayor's Banquet speech Cameron defended the 'hard-headed' approach to foreign policy on the grounds that:

'It will focus like a laser on defending and advancing Britain's national interest' ${ }^{83}$ In 2011 Cameron spoke of 'focussing our foreign policy on one objective: promoting Britain's 
national interest' ${ }^{84}$ In 2012 Cameron described it as 'standing up for our interests in the world' ${ }^{85}$ This much was to be expected, so of greater import here is the answer to research question 2a, How did liberal Conservatism define the British national interest? On the one hand, Cameron suggested 'our national interest is easily defined. It is to ensure our future prosperity and to keep our country safe in the years ahead' ${ }^{86}$ The national interest was rooted in economic and territorial security; in the former realm, especially, it was about 'making sure British interests get heard' ${ }^{87}$ On the other hand, the Prime Minister argued 'our national interests are affected more than ever by events well beyond our shores' and that is the reason 'why we need to maintain a global foreign policy' ${ }^{88}$ The interplay between British and international interests drew on the idea (considered above) that for liberal Conservatives the global political economy was characterized by complex interdependence in which even sizeable powers such as Britain had to react to events using flexible policy instruments drawing on all available sources of hard and soft power.

This is where values entered liberal Conservative discourse, helping to answer question $2 b$, What values did liberal Conservatism seek to promote or protect? In the first place Cameron constructed values as a fundamental part of Britain's historical identity: 'And we have values - national values that swept slavery from the seas, that stood up to both fascism and communism and that helped spread democracy and human rights around the planet'. These self-same values 'will drive us to do good around the world' ${ }^{89}$ A successful foreign policy, Cameron said in 2011, is 'one that both helps us and helps others' ${ }^{90}$ Hence, by 2013 Cameron could point to practices such as Britain's role in helping Taiwan recover from the devastation of Typhoon Haiyan and its opposition to the Assad regime in Syria in the context of standing up 'for the right values'. ${ }^{91}$ Yet, in a disavowal of the neo-Conservative strand to New Labour's foreign policy during the 'war on terror' for instance, Cameron also accepted that the promotion of British values had to be 'coupled with an increased willingness to accept moral diversity and the limitations of universal values. ${ }^{92}$ As Hague told the Foreign 
Affairs Committee in 2012: 'it is important not to generalize too much...if we want them to work with us in our interest and to develop more of our values. We mustn't push them down their throats, we have to be careful about that'. ${ }^{93}$ This was no 'shrinkage' from 'great' power responsibilities to the international community, however, and the intermingling of values and interests can be seen in two of the coalition government's most high profile foreign policy decisions in the period 2010-2015: first, to deploy military force (Operation Ellamy) as part of a multi-state coalition in the Libya intervention of March 2011; and second, not to deploy the military in August 2013 after parliament voted against using force against the Assad regime in the Syrian civil war. On both occasions discussion centred on the balance between humanitarian compassion and a commitment to upholding international humanitarian law on the one hand, and to the demands of the national interest on the other: in Syria, foe example, stopping the proliferation of chemical weapons or their future use. The difference between the outcomes, it appears, was that in the wide-ranging debate over Syria, parliament disagreed that the crisis was enough of a direct threat either to the national interest or to notional British 'values' to warrant a military response. ${ }^{94}$

When more 'limited' policy dilemmas were confronted it is evident that the coalition was better able to convince parliament and the country that British values and interests could both be upheld through strategic foreign policy practice. For example, in May 2012 the FCO launched a campaign to prevent conflict zone rape and sexual violence alongside the Special Envoy of the United Nations (UN) High Commissioner for Refugees, Angelina Jolie. This resulted amongst other outcomes in a G8 'Declaration on Preventing Sexual Violence in Conflict' in April 2013, ${ }^{95}$ and a UN 'Declaration on Ending Sexual Violence in Conflict', which by September 2013 had been endorsed by two-thirds of the international community. ${ }^{96}$ One outcome was that by the end of 2014 work was being undertaken by the UK and Canada on a joint mission to support the survivors of sexual rape and slavery allegedly perpetrated by ISIL in Iraq. ${ }^{97}$ As Jamie Gaskarth has argued, this example of an 'activist' foreign policy on 
the part of Britain shows that it is easier for policy entrepreneurs to build consensus behind policies that have relatively little impact on the vital national interests of other states (particularly those influential in bodies such as the P-5 of the UN), and where policies will directly benefit the lives of weaker members of society, enabling coalitions of the willing to be built behind targeted measures. It is also attractive when the policies do not pose a potential risk to the lives of British service personnel or civilian volunteers. ${ }^{98}$

To put the flesh on the bones of this point we can now examine how the coalition government addressed question 2c: how should British values and interests be promoted through its foreign policy? Key to this is to appreciate how the coalition entrenched New Labour's emphasis on the link between international aid, development and security, particularly through the establishment of DfID, backed by a Cabinet seat and substantial budget. It was affirmed by Cameron in his 2010 Lord Mayor's Banquet speech that despite economic travails the government would hold fast on its 2010 manifesto commitment to spend $0.7 \%$ of national income GDP on aid by $2013,{ }^{99}$ an ambition shared by both its coalition partners and the Labour opposition. ${ }^{100}$ Why? Because it 'literally saves lives. It helps prevent conflict'. ${ }^{101}$ In 2012 Cameron said he remained committed to its 'promises to the poorest' with a view to 'eradicating absolute poverty in our world' ${ }^{102}$ The first version of the FCO business plan for 2011-15, published in November 2010, explicitly linked the UK's promotion of human rights to its application of soft power globally. ${ }^{103}$

Good illustrations of how the coalition tried to enact a foreign policy 'that simultaneously served UK interests, whilst providing a net benefit to vulnerable non-citizens' was in its approach to the stabilisation of 'fragile' states and the arms trade. Both are well covered by Gilmore, ${ }^{104}$ so a few remarks about the beliefs underpinning state stabilisation will suffice to clarify the connections between discourse and practice. Responsibility for state stabilisation (lately during the Ebola crisis) has fallen on the civil-military Stabilisation Unit in the FCO, its funding governed by the NSC and thus with strong executive control from the 
centre of government. ${ }^{105}$ The merger of values and interests embodied in coalition practices around state stabilisation were illustrated by Cameron using the example of Pakistan. That by 2011 Pakistan was 'set to become the biggest recipient of British aid' was, said Cameron, not charity for charity's sake: 'Terrorism feeds on broken countries, so our response must go far beyond tackling the leadership of terrorist groups'. ${ }^{106}$ Aid in liberal Conservative discourse was an instrument of security alongside 'hard' military prowess, while the NSS represented state stabilisation as a means of addressing the threat to the UK from failed or failing states. ${ }^{107}$ Cameron fully subscribed to 'the moral argument for aid' because 'we have obligations to the poorest in the world'. Nonetheless, 'I also believe it is in our national interest. Isn't it better to help stop countries disintegrating - rather than end up dealing with the consequences for our own country: immigration, asylum terrorism?'. ${ }^{108}$ Two years earlier Hague had spelt out the economic - and therefore the interest -case for aid to developing countries even more clearly: 'We will be conscious that relatively small sums of money spent on conflict prevention can avert the need to spend vast sums on intervention or reconstruction aid, and is in alignment with our moral as well as national security duties'. ${ }^{109}$ In the liberal Conservative view, Britain - and the world - needed 'to change the way we do development' because targeted aid can 'help avoid crises before they explode into violence, requiring immense military spending' ${ }^{110}$ Conveniently, 'aid...can also contribute to a positive impression of Britain'. ${ }^{11}$

In sum, for liberal Conservatives altruistic actions could bring rewards of their own by safeguarding British interests over the long-term and by promoting Britain as a repository of 'positive' values in the international community. A values-based foreign policy could therefore enhance Britain's capacity to act out something approaching a 'great' role by delivering soft and hard power benefits. Reflecting on the Libyan revolution of 2011, for example, Cameron argued that humanitarian-focussed actions promoted British national interests: 'We saved civilian lives as [Muammar] Gaddafi's tanks bore down on Benghazi...And now we have the prospect of a new partner in the Southern Mediterranean, 
stronger alliances with our friends in the Gulf, and a refreshed defence relationship with France. I would argue that our action helped keep the Arab Spring alive'. ${ }^{112}$ So, there were intrinsic benefits to citizens beyond Britain's borders. The British themselves accrued longterm benefits from state and regional stabilisation as well as immediate security benefits because: 'in the last few days we have learnt that the new Libyan authorities have found chemical weapons that were kept hidden from the world', despite Gaddafi's earlier agreement to dismantle his weapons of mass destruction'. ${ }^{113}$

\section{Conclusion}

The first conclusion from this article concerns the methodology and sources used to enact this interpretivist account of liberal Conservatism. On the discourse side the main contributions of this research have been to cast light on the role conception for Britain in the world the coalition government saw emanating from its thinking on British identity, and on how the government translated its views on British values and British interests into foreign policy practices. For reasons of theoretical parsimony and word-count-management the article assumed that Conservative figures were the driving force behind British foreign policy, and they were the prime focus for study. This is not to deny that the Liberal Democrats had an input to British foreign policy thought or practices. It is rather to suggest that the make-up of the government in terms of the personnel in Cabinet and amongst the junior ministers, the evident synergies between the parties on the principles underlying British foreign policy before the 2010 election, and the ensuing coalition programme for government, seemed valid reasons to focus on Conservative thought. Clearly future research will be able to test and refine the findings on offer here: first, through interviews with outgoing ministers on both sides of the coalition; ${ }^{114}$ second, by reaching out to the history of Liberal Democrat foreign policy thought more widely; and finally via further identification and analysis of the interplay 
between Liberal Democrat and Conservative traditions in the proposal, debate, amendment and ratification of foreign policy legislation.

The second conclusion, looking ahead, is that key beliefs underpinning liberal Conservatism look set to inform the practices of the 2015 majority Conservative government. The label itself has, however, fallen out of use and there is clearly a heightened commitment on the part of the Foreign Secretary Philip Hammond to confronting 'hard' security dilemmas arising from terrorist organisations such as ISIL and associated security threats emanating from non-violent extremism and instability in Eastern Europe which may threaten the UK's energy security. ${ }^{115}$ The 2015 Conservative Party election manifesto also privileged the impending renegotiation about EU reform leading to the referendum by the end of 2017 and appealed to Conservative audiences by talking tough on scrapping the Human Rights Act. ${ }^{116}$ Nonetheless, key principles of liberal Conservatism were present in the manifesto's pledges to 'uphold British values', to introduce legislation committing governments to an annual spend of $0.7 \%$ of gross national income on development aid, and to 'support universal human rights'. In addition, the merger of values and interests remained central to Conservative thinking and the manifesto underlined the importance of the link between a strong economy and the preservation of British values and interests globally. Conservative affection for an Atlanticist leaning to British foreign policy via the 'special relationship' with the US was affirmed, ${ }^{117}$ as was its commitment to the Commonwealth and Angloshpere. ${ }^{118}$ Thus, it seems fair to end by reflecting that the liberal component of liberal Conservatism did not die with the Liberal Democrats leaving government because British foreign policy traditions have been remarkably durable and imbued with a liberal flavour for many years. Dilemmas have certainly arisen to bring about adaptations to both thought and practice, but even in periods of sometimes hefty international upheaval, British foreign policy decision-makers still look to time honoured British, not purely partisan, traditions to navigate a path through choppy global waters. 


\section{Author biography}

Oliver Daddow is Senior Lecturer in International Relations at the University of Chichester. He is the author of New Labour and the European Union: Blair and Brown's Logic of History (2011), Britain and Europe since 1945: Historiographical Perspectives on Integration (2004) and International Relations Theory: The Essentials (2013). He has previously edited Harold Wilson and European Integration: Britain's Second Application to Join the EEC (2003) and co-edited Interpreting Global Security (2014) and British Foreign Policy: The New Labour Years (2011). He has written articles in journals including International Affairs, Journal of Common Market Studies and Review of International Studies.

\footnotetext{
${ }^{1}$ My thanks for comments on an earlier draft of this paper go to the participants at the ECPR workshop in Mainz and latterly to Jamie Gaskarth, Ben Zala and the anonymous journal reviewers.

2 Jamie Gaskarth, British Foreign Policy (Cambridge: Polity, 2013); Tim Dunne, "When the Shooting Starts": Atlanticism in British Security Strategy', International Affairs, 80(5), 2004, pp.893-909; Christopher Kitchen, Constructing Identity in British Foreign Policy Towards Iran After 9/11, PhD thesis (University of Sheffield, 2013).

${ }^{3}$ Nicholas J. Wheeler and Tim Dunne, 'Good International Citizenship: A Third Way in British Foreign Policy', International Affairs, 74(4), 1998, pp.847-870; David McCourt, Britain and World Power since 1945: Constructing a Nation's Role in International Politics (Ann Arbor, MI.: University of Michigan Press, 2014).

${ }^{4}$ See usefully Jonathan Gilmore, 'The Uncertain Merger of Values and Interests in UK Foreign Policy', in Timothy Edmunds, Jamie Gaskarth and Robin Porter (eds) British Foreign Policy and the National Interest: Identity, Strategy and Security (Basingstoke: Palgrave Macmillan, 2014), pp.23-42; Rhiannon Vickers, 'Foreign Policy and International Development', in Matt Beech and Simon Lee (eds), The Conservative-Liberal Coalition: Examining the Cameron-Clegg Government (Basingstoke: Palgrave Macmillan, 2015), pp.227-242; Michael Clarke, 'The Coalition and Foreign Affairs', in Anthony Seldon and Mike Finn (eds) The Coalition Effect 2010-2015 (Cambridge: Cambridge University Press, 2015), pp.345-368.

${ }^{5}$ David Cameron, speech at the British American Project, 11 September $2006<$ http://www.guardian.co.uk/politics/2006/sep/11/conservatives.speeches> (31 January 2013). See also William Hague, 'The Future of British Foreign Policy', < http://www.conservatives.com/News/Speeches/2009/07/William_Hague_The_Future_of_British_Foreign_Polic y.aspx> 21 July 2009 (31 January 2013).

${ }^{6}$ Conservative Party, 'Invitation to Join the Government of Britain', pp.109-110 <

https://www.conservatives.com/ /media/files/activist\%20centre/press\%20and\%20policy/manifestos/manifesto2 010> (13 June 2015).

${ }^{7}$ Gilmore, 'The Uncertain Merger, p.23.

${ }^{8}$ Matt Beech, 'British Conservatism and Foreign Policy: Traditions and Ideas Shaping Cameron's Global View', British Journal of Politics and International Relations, 13(3), 2011, pp. 348-363.

${ }^{9}$ Liberal Democrats, Liberal Democrat Manifesto 2010 http://www.general-election-2010.co.uk/2010-generalelection-manifestos/Liberal-Democrat-Party-Manifesto-2010.pdf (11 June 2015), pp.56-69.

${ }^{10}$ Ben Wellings and Helen Baxendale, 'Euroscepticism and the Anglosphere: Traditions and Dilemmas in Contemporary English Nationalism', Journal of Common Market Studies, 53(1), 2015, pp.123-139; Daniel Hannan, 'The Anglosphere is Alive and Well, But I Wonder if it Needs a Better Name', The Telegraph, 2 March 2014 http://blogs.telegraph.co.uk/news/danielhannan/100261784/the-anglosphere-is-alive-and-well-but-iwonder-whether-it-needs-a-better-name/ (28 May 2015).
} 
${ }^{11}$ Clarke, 'The Coalition', p.347.

${ }^{12}$ The Coalition: Our Programme for Government, pp.19-20

<https://www.gov.uk/government/uploads/system/uploads/attachment_data/file/78977/coalition_programme_for _government.pdf> (10 June 2015).

${ }^{13}$ See Clarke, 'The Coalition', p.347.

${ }^{14}$ Julie Smith, 'Europe: The Coalition's Poisoned Chalice', in Anthony Seldon and Mike Finn (eds) The

Coalition Effect 2010-2015 (Cambridge: Cambridge University Press, 2015), pp.370-396 (pp.371).

${ }^{15}$ Philip Lynch, 'The Coalition and the European Union', in Matt Beech and Simon Lee (eds), The

Conservative-Liberal Coalition: Examining the Cameron-Clegg Government (Basingstoke: Palgrave Macmillan, 2015), pp.243-258 (pp.244-245).

16 Ibid., p.227.

${ }^{17}$ Peregrine Schwartz-Shea, and Dvora Yanow, Interpretive Research Design: Concepts and Processes (London: Routledge, 2012), p. 10.

${ }^{18}$ Paul Chilton, Analysing Political Discourse: Theory and Practice (London: Routledge, 2004), p. 54.

${ }^{19}$ HM Government, 'Review of Counter-Terrorism and Security Powers: Review Findings and Legislation', Cm 8004 (London: Her Majesty's Stationary Office, 2011).

${ }^{20}$ Richard Darlington, 'How will Clegg retaliate over the $0.7 \%$ aid law?', New Statesman, 8 May $2013<$ http://www.newstatesman.com/politics/2013/05/how-will-clegg-retaliate-over-07-aid-law> (13 June 2015).

${ }^{21}$ HM Government, 'International Development (Official Development Assistance Target) Act 2015', chapter 12 < http://www.legislation.gov.uk/ukpga/2015/12/pdfs/ukpga_20150012_en.pdf> (12 June 2015);

${ }^{22}$ Mark I. Vail, 'Between One-Nation Toryism and Neoliberalism: The Dilemmas of British Conservatism and

Britain's Evolving Place in Europe', Journal of Common Market Studies, 53(1), 2015, pp.106-22 (p.112).

${ }^{23}$ Vickers, 'Foreign Policy', p.229.

${ }^{24}$ Christopher Hill, 'Britain's Elusive Role in World Politics', British Journal of International Studies, 5(3), 1979, pp.248-259.

${ }^{25}$ For example Jamie Gaskarth, 'Discourses and Ethics: The Social Construction of British Foreign Policy', Foreign Policy Analysis, 2(4), 2009, pp.325-41 ; Oliver Daddow and Pauline Schnapper, 'Liberal Intervention in the Foreign Policy Thinking of Tony Blair and David Cameron', Cambridge Review of International Affairs, 26(2), 2013, pp.330-349; Gilmore, 'The Uncertain Merger'.

${ }^{26}$ Jamie Gaskarth, Robin Porter and Timothy Edmunds, 'Introduction', in Timothy Edmunds, Jamie Gaskarth and Robin Porter (eds) British Foreign Policy and the National Interest: Identity, Strategy and Security (Basingstoke: Palgrave Macmillan, 2014), pp.1-20 (p.9).

${ }^{27}$ Gaskarth, British Foreign Policy, p.61.

${ }^{28}$ William Hague, speech at the Annual Dinner of the CBI, 16 May $2012<$

http://www.cbi.org.uk/media/1487212/william_hague_cbi_annual_dinner_2012.pdf> (1 March 2013).

${ }^{29}$ Gaskarth, 'The National Interest'.

${ }^{30}$ Nick Ritchie, 'A Citizen's View of "National Interest", in Timothy Edmunds, Jamie Gaskarth and Robin Porter (eds) British Foreign Policy and the National Interest: Identity, Strategy and Security (Basingstoke: Palgrave Macmillan, 2014), pp.85-101.

${ }^{31}$ Mark Curtis, Web of Deceit: Britain's Real Role in the World (London: Vintage, 2003); David Wearing, 'Critical Perspectives on the Concept of the "National Interest": American Imperialism, British Foreign Policy and the Middle East', in Timothy Edmunds, Jamie Gaskarth and Robin Porter (eds) British Foreign Policy and the National Interest: Identity, Strategy and Security (Basingstoke: Palgrave Macmillan, 2014), pp.102-119.

${ }^{32}$ See Oliver Daddow, New Labour and the European Union: Blair and Brown's Logic of History (Manchester: Manchester University Press, 2011), especially chapter 9.

${ }^{33}$ Hague, 'The Future'.

${ }^{34}$ Philip Hammond, speech at the Lord Mayor's Easter Banquet, 25 March $2015<$

https://www.gov.uk/government/speeches/foreign-secretary-speech-at-the-lord-mayors-easter-banquet> (13 June 2015).

${ }^{35}$ HM Government, 'A Strong Britain in an Age of Uncertainty: The National Security Strategy', October 2010 $<$

http://www.direct.gov.uk/prod_consum_dg/groups/dg_digitalassets/@dg/@en/documents/digitalasset/dg_19163 9.pdf> (accessed 1 March 2013).

${ }^{36}$ David Cameron, speech at Lord Mayor's Banquet, 15 November $2010<$

https://www.gov.uk/government/speeches/speech-to-lord-mayors-banquet> (30 January 2013); David Cameron, speech to Lord Mayor's Banquet, 14 November 2011 < http://www.number10.gov.uk/news/lord-mayorsbanquet/> (31 January 2013); Hague, 'The Future'.

${ }^{37}$ Cameron, speech to Lord Mayor's Banquet 2010. See also Hague, 'The Future'.

${ }^{38}$ Hammond, speech at Lord Mayor's Easter Banquet 2015.

${ }^{39}$ Cameron, speech to Lord Mayor's Banquet 2010. 
${ }^{40}$ Cameron Cameron, speech to Lord Mayor's Banquet 2011; Cameron, speech to Lord Mayor's Banquet 2012.

${ }^{41}$ Cabinet Office, 'Britain is GREAT', https://www.gov.uk/britainisgreat. For discussion see James Pamment,

'Putting the GREAT Back into Britain: National Identity, Public-Private Collaboration and Transfers of Brand Equity in 2012's Global Promotional Campaign', British Journal of Politics and International Relations, 17(2), 2015, pp.260-283.

${ }^{42}$ Philip Hammond, speech at Conservative Party conference, 1 October $2014<$

http://press.conservatives.com/post/98879965545/philip-hammond-speech-to-conservative-party> (13 June

2015); David Cameron, speech to Lord Mayor's Banquet, 11 November 2013

<https://www.gov.uk/government/speeches/lord-mayors-banquet-2013-prime-ministers-speech> (13 June 2013).

${ }^{43}$ Cameron, speech to Lord Mayor's Banquet 2010.

${ }^{44}$ Cameron, speech to Lord Mayor's Banquet 2012; Hague, speech at CBI. For a flavour of this criticism see For instance David Miliband cited in Benedict Brogan, 'As William Hague jets around the globe, has he left his mojo behind?' < http://blogs.telegraph.co.uk/news/benedictbrogan/100072662/as-william-hague-jets-around-theglobe-has-he-left-his-mojo-behind/> 19 January 2011 (2 March 2013).

${ }^{45}$ Cameron, speech to Lord Mayor's Banquet 2011.

${ }^{46}$ Foreign Affairs Committee, 'FCO Performance and Finances 2011-2012', 19 April $2013<$ http://www.publications.parliament.uk/pa/cm201213/cmselect/cmfaff/690/69006.htm> (14 June 2015).

${ }^{47}$ William Hague, speech, 'The Best Diplomatic Service in the World: Strengthening the Foreign and

Commonwealth Office as an Instution', London, 8 September $2011<$

https://www.gov.uk/government/speeches/the-best-diplomatic-service-in-the-world-strengthening-the-foreignand-commonwealth-office-as-an-institution> (14 June 2015).

${ }^{48}$ Cameron, speech to Lord Mayor's Banquet 2012.

${ }^{49}$ Cameron, speech to Lord Mayor's Banquet 2010.

${ }^{50}$ Cabinet Office 'National Security Council', undated < https://update.cabinetoffice.gov.uk/content/nationalsecurity-council> (1 March 2013).

${ }^{51}$ Hammond, speech at Conservative Party conference.

${ }^{52}$ On which Joseph S. Nye, Soft Power: The Means to Success in World Politics (New York: Public Affairs, 2004).

${ }^{53}$ Hammond, speech at lord Mayor's Easter Banquet 2015.

${ }^{54}$ Cameron, speech to Lord Mayor's Banquet 2013.

${ }^{55}$ Hammond, speech at lord Mayor's Easter Banquet 2015.

${ }^{56}$ See Clarke, 'The Coalition', pp.346-347.

${ }^{57}$ Hague, 'Foreign Policy'.

${ }^{58}$ HM Government, National Security Strategy, p. 4.

${ }^{59}$ Cameron, speech to Lord Mayor's Banquet 2013.

${ }^{60}$ Christopher Hill and Sarah Beadle, The Art of Attraction: Soft Power and the UK's Role in the World

(London: British Academy, 2014), p.3.

${ }^{61}$ Hague, 'The Future'. See also Cameron, speech to Lord Mayor's Banquet 2010.

${ }^{62}$ Cameron, speech to Lord Mayor's Banquet 2012.

${ }^{63}$ William Hague, 'Foreign Policy in a Networked World', 1 July $2010<$

http://www.conservatives.com/News/Speeches/2010/07/William_Hague_Britains_Foreign_Policy_in_a_Networ ked_World.aspx> (31 January 2013).

${ }^{64}$ Cameron, speech to Lord Mayor's Banquet 2010.

${ }^{65}$ Cameron, speech to Lord Mayor's Banquet 2012.

${ }^{66}$ Cameron, speech to Lord Mayor's Banquet 2010. See also Hague, 'Foreign Policy'.

${ }^{67}$ Cameron, speech to Lord Mayor's Banquet 2012.

${ }^{68}$ Cameron, speech to Lord Mayor's Banquet 2010

${ }^{69}$ Cameron, speech to Lord Mayor's Banquet 2010.

${ }^{70}$ Hammond, speech at lord Mayor's Easter Banquet 2015.

${ }^{71}$ Cameron, speech to Lord Mayor's Banquet 2010.

${ }^{72}$ Hammond, speech at lord Mayor's Easter Banquet 2015.

${ }^{73}$ Tony Blair, speech at the Economic Club, Chicago, 22 April, <

http://www.pbs.org/newshour/bb/international/jan-june99/blair_doctrine4-23.html> (14 February 2013).

Emphasis added.

${ }^{74}$ Cameron, speech to Lord Mayor's Banquet 2010.

${ }^{75}$ Chatham House, 'Session Two: National Politics and the Global Economy', London Conference 2015

(London: Royal Institute of International Affairs, 2015) < http://www.chathamhouse.org/sites/files/chathamhouse/London\%20Conference\%202015\%20-

\%20Background\%20Paper\%20-\%20Session\%20Two.pdf> (13 June 2015).

${ }^{76}$ Hammond, speech at lord Mayor's Easter Banquet 2015. 
${ }^{77}$ Cameron, speech to Lord Mayor's Banquet 2010.

${ }^{78}$ Philip Hammond, speech on climate change, Boston, 10 October $2014<$

http://www.businessgreen.com/bg/opinion/2375010/philip-hammonds-first-speech-on-climate-change-in-full> (13 June 2015).

${ }^{79}$ Cameron, speech to Lord Mayor's Banquet 2011.

${ }^{80}$ Cameron, speech to Lord Mayor's Banquet 2011.

${ }^{81}$ Hammond, speech at lord Mayor's Easter Banquet 2015.

${ }^{82}$ Hague, 'The Future'.

${ }^{83}$ Cameron, speech to Lord Mayor's Banquet 2010.

${ }^{84}$ Cameron, speech to Lord Mayor's Banquet 2011.

${ }^{85}$ Cameron, speech to Lord Mayor's Banquet 2012.

${ }^{86}$ Cameron, speech to Lord Mayor's Banquet 2010.

${ }^{87}$ Cameron, speech to Lord Mayor's Banquet 2011.

${ }^{88}$ Cameron, speech to Lord Mayor's Banquet 2010.

${ }^{89}$ Cameron, speech to Lord Mayor's Banquet 2010. See also William Hague, speech at Conservative Party conference, 5 October 2011, < http://www.politics.co.uk/comment-analysis/2011/10/05/william-hague-speechin-full> (31 January 2013).

${ }^{90}$ Cameron, speech to Lord Mayor's Banquet 2011.

${ }^{91}$ Cameron, speech to Lord Mayor's Banquet, 112013.

${ }^{92}$ Gilmore, 'The Uncertain Merger', p.31.

${ }^{93}$ Cited in Gilmore, 'The Uncertain Merger', p.31.

${ }^{94}$ Gilmore, 'The Uncertain Merger', p.33.

${ }^{95}$ G8 and Foreign and Commonwealth Office, 'Declaration on Preventing Sexual Violence in Conflict', 11 April $2013<$ https://www.gov.uk/government/uploads/system/uploads/attachment_data/file/185008/G8_PSVI_Declaration__FINAL.pdf> (14 June 2015).

${ }^{96}$ United Nations, 'A Declaration of Commitment to End Sexual Violence in Conflict', 24 September $2013<$ https://www.gov.uk/government/uploads/system/uploads/attachment_data/file/274724/A_DECLARATION_OF _COMMITMENT_TO_END_SEXUAL_VIOLENCE_IN_CONFLICT.pdf> (14 June 2015).

${ }^{97}$ Foreign and Commonwealth Office, 'UK and Canada announce joint mission to Iraq to support survivors of sexual violence by ISIL', 6 October $2014<$ https://www.gov.uk/government/news/uk-and-canada-respond-tosexual-violence-by-isil-in-iraq > (14 June 2015).

${ }^{98}$ Gaskarth, 'Britain in the World', p.58.

${ }^{99}$ Conservative Party, 'Invitation', p.117.

${ }^{100}$ Liberal Democrats, 'Liberal Democrat Manifesto 2010' < http://www.general-election-2010.co.uk/2010general-election-manifestos/Liberal-Democrat-Party-Manifesto-2010.pdf> (13 June 2015), p.57; Labour Party, 'The Labour Party Manifesto 2010: A Future Fairl For All' <

http://www2.labour.org.uk/uploads/TheLabourPartyManifesto-2010.pdf> (13 June 2015), p.10:6.

${ }^{101}$ Cameron, speech to Lord Mayor's Banquet 2010.

${ }^{102}$ Cameron, speech to Lord Mayor's Banquet 2012.

${ }^{103}$ Foreign Affairs inquiry, 'Human Rights Policy at the FCO'.

${ }^{104}$ Gilmore, 'The Uncertain Merger', pp.30-39.

${ }^{105}$ Gilmore, 'The Uncertain Merger', p.34. For details see Stabilisation Unit, 'About Us' < https://www.gov.uk/government/organisations/stabilisation-unit/about> (14 June 2013).

${ }^{106}$ Cameron, speech to Lord Mayor's Banquet 2011.

${ }^{107}$ Gilmore, 'The Uncertain Merger', p.34.

${ }^{108}$ Cameron, speech to Lord Mayor's Banquet 2011.

${ }^{109}$ Hague, 'The Future'.

${ }^{110}$ Cameron, speech to Lord Mayor's Banquet 2011.

${ }^{111}$ Hague, 'Foreign Policy'.

${ }^{112}$ Cameron, speech to Lord Mayor's Banquet 2011.

${ }^{113}$ Ibid.

${ }^{114}$ Promised in Anthony Seldon and Peter Snowdon, Cameron at Ten (London: William Collins, forthcoming, 2015).

${ }^{115}$ Conservative Party, The Conservative Party Manifesto 2015 < https://www.conservatives.com/Manifesto> (10 June 2015), pp.61-63.

${ }^{116}$ Ibid., pp.72-73.

${ }^{117}$ Corroborating Dunne, "'When the Shooting Starts"'.

${ }^{118}$ Conservative Party, The Conservative Party Manifesto., pp.75-76. 